\title{
Evaluasi Prosedur Pemberian Pembiayaan dan Hubungannya Dengan Kredit Macet Pada Koperasi Tunas Perkebunan Belitang OKU Timur
}

\author{
Santi Puspita \\ Manajemen, Fakultas Ekonomi Universitas PGRI Palembang,santipuspita@univpgri-palembang.ac.id
}

\begin{abstract}
ABSTRAK
Penelitian ini dilakukan untuk mengetahui prosedur pemberian pembiayaan dan hubungannya dengan kredit macet pada Koperasi Tunas Perkebunan Belitang OKU Timur. Metode pengumpulan data yang digunakan dalam penelitian ini adalah metode observasi, wawancara dan studi kepustakaan dan data yang digunakan data primer dan sekunder. Pelaksanaan prosedur pemberian pembiayaan pada Koperasi Tunas Perkebunan Belitang OKU Timur belum terlaksana dengan baik dikarenakan bagian pembiayan yang tugasnya melaksanakan prosedur pemberian pembiayaan kurang mengadakan pengecekan terhadap kelayakan besaran pembiayaan yang diberikan kepada calon peminjam (anggota) dibandingkan dengan tingkat penghasilannya, kekurang kehati-hatian dalam memberikan pinjaman, dan kurannya pengecekan terhadap informasi yang telah diberikan oleh para anggota, ini lah yang mengakibatkan kredit macet pada Koperasi Tunas Perkebunan Belitang OKU Timur. Selain faktor bagian pembiayaan yang melaksanakan prosedur pemberian kredit, kredit macet dapat pula terjadi dari sudut anggota itu sendiri, dapat ditentukan dengan melihat kondisi kehidupan anggota sehari-hari dengan menggunakan analisis 5 C yaitu: character, capacity, capital, collateral, dan condition.
\end{abstract}

Kata Kunci: Prosedur Pemberian Biaya, Kredit Macet

\section{A. PENDAHULUAN}

Perekonomian

Indonesia, dilaksanakan oleh empat lembaga yaitu BUMN, BUMD, Swasta dan Koperasi. Sedangkan yang menjadi sokoguru perekonomian menurut UndangUndang Dasar adalah koperasi. Berdasarkan Undang-Undang 1945 pasal 33 ayat 1 menyatakan bahwa perekonomian Indonesia disusun sebagai usaha bersama berdasarkan atas asas kekeluargaan.

Selanjutnya penjelasan pasal 33 antara lain menyatakan bahwa kemakmuran masyarakatlah yang diutamakan bukan kemakmuran untuk perseorangan dan bangunan perusahaan yang sesuai dengan itu adalah koperasi. Penjelasan pasal 33 tersebut menempatkan koperasi baik dalam kedudukan sebagai sokoguru perekonomian nasional maupun sebagai pusat tata perekonomian nasional.
Peraturan perundang-undangan perkoperasian diatur berdasarkan Undang-Undang No. 25 Tahun 1992 tersebut menjadi landasan hukum yang diharapkan mampu mendorong koperasi agar dapat bertumbuh dan berkembang menjadi lebih kuat dan mandiri. Undang-undang koperasi beserta peraturan pelaksanaanya bertujuan untuk memperjelas dan mempertegas jati diri, tujuan, kedudukan, peran manajemen, keusahaan dan permodalan serta pembinaan koperasi, sehingga dapat lebih menjamin terwujudnya kehidupan koperasi.

Berbagai jenis koperasi lahir seiring dengan adanya pembangunan dan mempunyai tujuan berbeda-beda dalam menjalankan kegiatan usahanya, dimana salah satunya adalah Koperasi Tunas Perkebunan Belitang OKU Timur, dalam menjalankan kegiatan usahanya baik 
dalam hal pengumpulan dana, jasa, dan produk yang berupa pemberian pembiayaan yang berdasarkan prinsip syariah atau berlandaskan nilai-nilai Islam.

Adapun dalam pemberian pinjaman kredit atau dalam istilah koperasi syariah adalah pemberian pembiayaan, nasabah harus mengikuti beberapa prosedur yang telah ditetapkan oleh Koperasi Tunas Perkebunan Belitang OKU Timur, karena dalam prosedur tersebut menyangkut semua urutan kegiatan yang disusun untuk menjamin transaksi pembiayaan yang terjadi. Bila pemberian pembiayaan diberikan tanpa adanya prosedur, kemungkinan dalam pemberian pembiayaan tersebut akan mengalami berbagai masalah seperti dalam pembayaran angsuran pinjaman.
Koperasi Tunas Perkebunan Belitang OKU Timur yang telah berdiri dari tahun 1998 sampai dengan sekarang masih mengalami masalah yang cukup merisaukan yaitu adanya pemberian pembiayaan yang macet untuk tiap tahunnya.

Bagian pembiayan yang tugasnya melaksanakan prosedur pemberian kredit kurang mengadakan pengecekan terhadap kelayakan besaran pembiayaan yang diberikan kepada calon peminjam (anggota) dibandingkan dengan tingkat penghasilannya, kekurang kehatihatian dalam memberikan pinjaman, ini lah yang mengakibatkan kredit macet pada Koperasi Tunas Perkebunan Belitang OKU Timur. Kredit macet yang terjadi pada Koperasi Tunas Perkebunan Belitang OKU Timur dari Tahun 2015 sampai dengan 2017 adalah sebagai berikut:

Tabel 1

Koperasi Tunas Perkebunan Belitang OKU Timur

Pemberian Pembiayaan Yang Macet

Tahun 2015 s/d 2017

\begin{tabular}{|c|c|c|c|}
\multicolumn{4}{|c|}{ (Rupiah) } \\
\hline 2015 & 238.100 .000 & 50.960 .000 & $\begin{array}{c}\text { Persentase kredit } \\
\text { macet }\end{array}$ \\
2016 & 510.593 .075 & 100.900 .000 & $21 \%$ \\
2017 & 683.541 .470 & 150.750 .000 & $19 \%$ \\
\hline
\end{tabular}

Sumber : Koperasi Tunas Perkebunan Belitang OKU Timur

Pada tabel 1 menunjukkan bahwa pada tahun 2015, jumlah kredit sebesar Rp 238.100.000, sedangkan jumlah kredit macet sebesar Rp 50.960.000 atau $21 \%$. Pada tahun 2016 jumlah kredit sebesar Rp 510.593.075, sedangkan jumlah kredit macet mengalami kenaikan sebesar Rp 100.900 .000 atau $19 \%$. Pada tahun 2017 jumlah kredit mengalami peningkatan sebesar Rp 685.541.470 dan jumlah kredit macet meningkat sebesar $\mathrm{Rp} 150.750 .000$ atau $22 \%$, apabila kenaikan kredit macet tidak dapat dikurangi maka akan menyebabkan Koperasi Tunas Perkebunan Belitang OKU Timur dapat kesulitan dalam memberikan atau menambah pembiayaan untuk anggota koperasi lain.

\section{B. RUMUSAN MASALAH}

Dari latar belakang masalah di atas dapatlah dirumuskan beberapa masalah yaitu : 
a. Bagaimana prosedur pemberian pembiayaan pada Koperasi Tunas Perkebunan Belitang OKU Timur?

b. Apa saja yang menyebabkan meningkatnya jumlah pembiayaan yang macet pada Koperasi Tunas Perkebunan Belitang OKU Timur?

\section{KAJIAN TEORI}

\section{1) Pengertian Koperasi}

Secara umum koperasi dipahami sebagai perkumpulan orang yang secara sukarela mempersatukan diri untuk memperjuangkan peningkatan kesejahteraan ekonomi mereka, melalui pembentukan sebuah badan usaha yang dikelola secara demokratis.

Disamping itu, koperasi juga berfungsi sebagai wadah untuk mengorganisir pendayagunaan dan pemanfaatan sumber daya yang dimiliki anggota koperasi.

Koperasi adalah badan usaha yang mengorganisir pemanfaatan dan pendayagunaan sumber daya ekonomi para anggotanya atas dasar prinsipprinsip koperasi dan kaidah usaha ekonomi untuk meningkatkan taraf hidup anggota pada khususnya dan masyarakat daerah kerja pada umumnya. Dengan demikian koperasi merupakan gerakan ekonomi rakyat dan sokoguru perekonomian nasional (Rudianto, 2006:2)

Sementara itu menurut Pasal 1 UU No.25/1992 yang dimaksud dengan koperasi di Indonesia adalah suatu badan usaha yang lebih memiliki dasar asas kekeluargaan. Koperasi adalah badan usaha yang beranggotakan orang-seorang atau badan hukum koperasi dengan melandaskan kegiatan berdasarkan prinsip koperasi sekaligus sebagai gerakan ekonomi rakyat yang berdasarkan atas asas kekeluargaan.

Dari definisi koperasi tersebut di atas dapat penulis simpulkan, bahwa koperasi merupakan badan usaha yang beranggotakan orang-seorang atau badan hukum yang mengkoordinir pemanfaatan dan pendayagunaan sumber daya ekonomi para anggotanya berdasarkan prinsip koperasi yang berdasarkan asas kekeluargaan.

\section{2) Jenis-Jenis Koperasi}

Berdasarkan bidang usaha dan jenis anggotanya, menurut PSAK No. 27 tahun 2004, koperasi dapat digolongkan ke dalam beberapa jenis koperasi, yaitu :

a. Koperasi Simpan pinjam

Koperasi simpan pinjam adalah koperasi yang bergerak dalam bidang pemupukan simpanan dana dari para anggotanya, untuk kemudian dipinjamkan kembali kepada para anggota yang memerlukan bantuan dana.

b. Koperasi Konsumen

Koperasi konsumen adalah koperasi yang anggotanya para konsumen akhir atau pemakai barang atau jasa ( Koperasi yang mengelola toko serba ada, mini market dan sebagainya).

c. Koperasi Pemasaran

Koperasi pemasaran adalah koperasi yang anggotanya para produsen atau pemilik barang atau penyedia jasa. Koperasi pemasaran adalah koperasi yang dibentuk terutama untuk membantu para anggotanya memasarkan barang-barang yang mereka hasilkan

d. Koperasi Produsen

Koperasi produsen adalah koperasi yang anggotanya tidak memiliki badan usaha sendiri, tetapi bekerja sama dalam wadah koperasi untuk menghasilkan dan memasarkan barang atau jasa. 
Menurut Hendar (2005:235) Jenis koperasi yang sesuai dengan pasal 16 Undang-undang Nomor 25 Tahun 1992

a. Koperasi Simpan Pinjam (KSP)/ Koperasi kredit

Sesuai peraturan pemerintah Nomor 9 tahun 1995 pasal 1, bahwa koperasi simpan pinjam adalah koperasi yang kegiatannya hanya usaha simpan pinjam. Keanggotaan koperasi simpan pinjam pada prinsipnya bebas bagi semua orang yang memenuhi untuk menjadi anggota koperasi dan orang-orang dimaksud mempunyai kegiatan usaha atau mempunyai kepentingan ekonomi yang sama. Misalnya KSP dengan anggota petani.

b. Koperasi Konsumen

Sebagai pemilik dan pengguna jasa koperasi, anggota berpartisipasi aktif dalam kegiatan koperasi. Keanggotaan koperasi konsumen atau pendiri koperasi konsumen adalah kelompok masyarakat, missal kelompok PKK, karang taruna dan lain-lain. Koperasi konsumen menyalurkan barang-barang konsumen untuk keperluan anggota dan di samping pelayanan untuk anggota bisa juga untuk umum.

c. Koperasi Produsen

Adalah koperasi yang anggotanya orang-orang yang menghasilkan barang, misalnya :

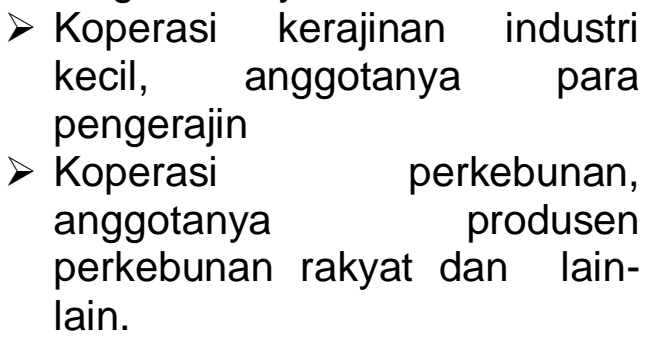

d. Koperasi Pemasaran

Adalah koperasi beranggotakan orang-orang yang mempunyai kegiatan di bidang pemasaran barang-barang dagang, misalnya :

$>$ Koperasi pemasaran ternak sapi, anggotanya adalah pedagag sapi

$>$ Koperasi pemasaran elektronik, anggotanya adalah pedagan barang-barang elektronik dan lain-lain.

e. Koperasi Jasa

Didirikan untuk memberikan pelayanan (jasa) kepada para anggotanya. Ada beberapa koperasi jasa antara lain :

$>$ Koperasi angkutan memberikan jasa angkutan barang atau orang, koperasi angkutan didirikan oleh orangorang yang mempunyai kegiatan di bidang jasa angkutan barang atau orang dan lain-lain.

\section{3) Prinsip-Prinsip Koperasi}

Prinsip-prinsip pengelolaan koperasi merupakan penjabaran lebih lanjut dari asas kekeluargaan yang dianutnya. Prinsip-prinsip koperasi ini biasanya mengatur baik hubungan antar koperasi dengan para anggotanya, hubungan antar sesama anggota koperasi, pola kepengurusan organisasi koperasi serta mengenai tujuan yang ingin dicapai oleh koperasi sebagai lembaga ekonomi yang berasas kekeluargaan. Selain itu, prinsip-prinsip koperasi biasanya juga mengatur pola kepengelolaan usaha koperasi. Sebab itu, secara lebih terinci, ia juga mengatur pola kepemilikan modal kopoerasi serta pola pembagian sisa hasil usahanya. Penyusunan prinsip-prinsip koperasi di Indonesia tidak terlepas dari sejarah dan perkembangan prinsip koperasi Internasional.

Sebagaimana dinyatakan di dalam Pasal 5 Ayat 1 Undang-undang No. 25/1992, koperasi Indonesia 
melaksanakan prinsip-prinsip

keanggotaan (Rudianto, 2006:5).

1. Keanggotaan bersifat sukarela dan terbuka.

Karena itu tidak seorang pun yang boleh dipaksa oleh orang lain untuk menjadi anggota koperasi.

2. Pengelolaan dilakukan secara demokratis.

Penerapan prinsip ini di dalam koperasi dilakukan dengan mengupayakan sebanyak mungkin anggota koperasi di dalam pengambilan keputusan koperasi.

3. Pembagian sisa hasil usaha dilakukan secara adil dan sebanding dengan besarnya jasa masing-masing anggota.

Koperasi tidak menggunakan istilah laba atau keuntungan untuk menunjukkan selisih antara penghasilan yang diterima selama periode tertentu dengan pengorbanan yang dikeluarkan untuk memperoleh penghasilan itu. Jasa anggota diukur berdasarkan jumlah kontribusi masing-masing terhadap pembentukan SHU ini. Ukuran kontribusi yang digunakan adalah jumlah transaksi anggota dengan koperasi selama periode tertentu.

4. Pemberian balas jasa yang terbatas pada modal.

Pembatasan bunga atas modal merupakan cerminan bahwa koperasi selain menaruh perhatian terhadap pemberian imbalan yang wajar terhadap partisipasi anggotanya, juga mendorong dan menumbuhkan rasa kesetiakawanan antar sesama anggota koperasi.

5. Kemandirian

Agar koperasi dapat mandiri maka koperasi harus mengakar kuat dalam kehidupan masyarakat dan agar dapat mengakar kuat koperasi harus harus dapat diterima oleh masyarakat. Agar dapat diterima masyarakat, koperasi harus memperjuangkan kepentingan dan peningkatan kesejahteraan ekonomi masyarakat.

\section{4) Keanggotaan Koperasi}

Keanggotaan koperasi termasuk salah satu unsur yang menentukan dalam organisasi koperasi. Tanpa anggota, jelas tidak mungkin koperasi berdiri, apa lagi melaksanakan usahanya. Karena itu, kedudukan anggota dalam koperasi secara hukum adalah suatu keharusan dan sebagai konsekuensinya anggota tersebut memiliki hak serta kewajiban umum.

Berkaitan dengan keanggotaan koperasi ditegaskan dalam pasal 17 Undang-Undang Nomor 25 Tahun 1992 tentang Perkoperasian yang menyebutkan :

> Anggota koperasi adalah pemilik dan sekaligus pengguna jasa koperasi

Keanggotaan koperasi dicatat dalam buku daftar anggota.

Dalam kedudukannya sebagai pengguna jasa atau pelanggan dari koperasinya, anggota harus berpartisipasi aktif dalam kegiatan usaha koperasi. Kegiatan usaha koperasi pada dasarnya adalah kegiatan yang diputuskan oleh anggota dan diselenggarakan untuk kepentingan anggota sendiri.

Selanjutnya dalam koperasi bukti kepemilikan anggota diwujudkan dengan pelaksanaan kewajiban membayar simpanan pokok yang dibuktikan dalam bentuk sertifikat. Ketentuan tersebut memperjelas pengertian keanggotaan koperasi, jika dibandingkan dengan misalnya pengertian keanggotaan pada perkumpilan/organisasi masyarakat, atau yayasan, atau perseroan terbatas 
yang tidak mengenal istilah anggota, tetapi menggunakan pengertian pemegang saham. Atas dasar itu anggota koperasi adalah baku atau normative. Maka pada dasarnya anggota koperasi adalah aktif dalam melaksanakan hak dan kewajibannya, baik sebagai pemilik maupun sebagai pengguna jasa koperasi.

Kedudukan hukum anggota koperasi sebagaimana dimaksud di atas, memberi kekuatan, kemantapan, perlindungan dan rasa aman bagi mereka yang sudah atau yang akan menjadi anggota koperasi, maka mengenai keanggotaan ini merupakan identitas khusus yang menjadi dasar atau pondasi yang kokoh bagi suatu organisasi.

\section{5) Permodalan Koperasi}

Sesuai dengan Undang-Undang Nomor 25 Tahun 1992 tentang Perkoperasian, modal koperasi terdiri atas modal sendiri dan modal pinjaman. Sebagai badan usaha, koperasi harus memiliki modal ekuitas sebagai modal perusahaan. Atas dasar itu kedudukan dan status modal koperasi secara hukum dipertegas dengan menetapkan modal sendiri yang merupakan modal ekuitas, sedangkan modal pinjaman merupakan modal penunjang. Ekuitas adalah selisih antara total kekayaan suatu badan usaha dengan total utangnya (Hendar, Kusnadi, 2005:255).

Menurut Hendar, Kusnadi (2005:255) dalam pasal 41 UndangUndang Nomor 25 Tahun 1992 tentang Perkoperasian menyebutkan bahwa modal koperasi terdiri atas:

1). Modal Sendiri

Modal sendiri dapat berasal dari :

- Simpanan Pokok

Adalah jumlah nilai uang tertentu yang sama banyaknya setiap anggota yang harus disetorkan pada waktu masuk menjadi anggota. Jenis simpanan pokok ini tidak dapat diambil kembali selama orang tersebut masih menjadi anggota koperasi.

Simpanan Wajib

Adalah jumlah simpanan tertentu yang harus dibayarkan oleh anggota dalam waktu dan kesempatan tertentu, misalnya sebulan sekali. Jenis simpanan wajib ini dapat diambil kembali dengan cara-cara yang diatur lebih lanjut dalam anggaran dasar, anggaran rumah tangga, dan keputusan-keputusan rapat anggota.

> Simpanan Sukarela

Adalah suatu jumlah tertentu yang diserahkan oleh anggota atau bukan anggota terhadap koperasi atas kehendak sendiri sebagai simpanan. Simpanan jenis ini dapat diambil kembali oleh pemilik simpanannya setiap saat. Karena itu simpanan sukarela tidak dapat dikelompokkan sebagai modal anggota di dalam koperasi dan dikelompokkan sebagai hutang jangka pendek.

2). Modal Pinjaman

Modal pinjaman dapat berasal dari anggota, koperasi lainnya dan/atau anggotanya, bank dan lembaga keuangan lainya.

3). Modal Sumbangan

Adalah sejumlah uang atau barang modal yang dapat dinilai dengan uang yang diterima dari pihak lain yang bersifat hibah dan tidak mengikat. Modal sumbangan tidak dapat dibagikan kepada koperasi selama koperasi belum dibubarkan.

3). Modal Penyertaan

Adalah sejumlah uang atau barang modal yang dapat dinilai dengan uang yang ditanamkan oleh pemodal untuk menambah dan memperkuat struktur permodalan 
dalam meningkatkan usaha koperasi.

4). Cadangan

Adalah bagian dari sisa hasil usaha yang disisihkan sesuai dengan ketentuan anggaran dasar atau ketetapan rapat anggota.

5). Sisa Hasil Usaha

Adalah selisih antara penghasilan yang diterima selama periode tertentu dengan pengorbanan (beban) yang dikeluarkan untuk memperoleh penghasilan itu dan belum dibagikan kepada anggota.

\section{6) Fungsi Unsur-Unsur Organisasi Koperasi}

Jika dilihat dari segi fungsi, maka pada dasarnya terdapat pembagian tugas antara rapat anggota, pengurus, pengawas, dan pengelola yang intinya sebagai berikut:

a) Rapat Anggota

Pemegang kekuasaan tertinggi dan menetapkan kebijakan umum di bidang organisasi, manajemen dan usaha koperasi.

b) Pengurus

Pemegang kuasa rapat anggota dan melaksanakan kebijakan umum serta mengelola organisasi dan usaha koperasi, sebagai mana ditetapkan oleh rapat anggota.

c) Pengawas

Mewakili anggota melakukan pengawasan terhadap pelaksanaan kebijakan pengelolaan koperasi yang dilaksanakan oleh pengurus dan pengelola.

d) Pengelola

Melakukan pengelolan usaha dengan kuasa dan wewenang yang diberikan oleh pengurus.

\section{7) Pengertian Sistem dan Prosedur}

a) Pengertian Sistem Menurut Mulyadi (2015:2) Sistem adalah sekelompok unsur yang erat berhubungan satu dengan lainnya, yang berfungsi bersama-sama untuk mencapai tujuan tertentu. Sistem diciptakan untuk menangani sesuatu yang berulang kali atau yang secara rutin terjadi.

\section{b) Pengertian Prosedur} Menurut Mulyadi

(2015:5)

Prosedur adalah suatu urutan kegiatan klerikal (clerical operation), biasanya melibatkan beberapa orang dalam satu depertemen atau lebih, yang dibuat untuk menjamin penanganan secara seragam transaksi instansi yang terjadi berulang-ulang.

Prosedur merupakan suatu pekerjaan kerani (clecial) biasanya melibatkan beberapa orang dalam suatu bagian atau lebih yang disusun untuk menjamin adanya perlakukan yang seragam terhadap transaksitransaksi perusahaan.

Dari pengertian prosedur tersebut di atas, penulis dapat simpulkan bahwa prosedur merupakan suatu kegiatan yang biasanya melibatkan beberapa orang dalam suatu bagian atau lebih, yang di buat untuk menjamin penanganan suatu perlakuan yang seragam terhadap transaksi yang berulang-ulang.

Prosedur dalam pemberian pembiayaan oleh perusahaan secara umum antar perusahaan yang satu dengan perusahaan yang lain tidakjauh berbeda. Syarat-syarat atau petunjuk tindakan-tindakan yang harus dilakukan sejak diajukannya permohonan nasabah sampai dengan lunasnya suatu kredit yang diberikan oleh perusahaan.

\section{8) Pengertian}

a) Pengertian Piutang

Piutang adalah klaim koperasi atas uang, barang atau jasa kepada pihak lain akibat transaksi dimasa lalu. 
Tagihan yang tidak disertai dengan janji tertulis disebut piutang. Itu berarti, suatu aktivitas dapat dikelompokkan sebagai piutang jika memenuhi beberapa persyaratan, antara lain :

$>$ Piutang tersebut timbul akibat transaksi dimasa lalu

$>$ Piutang tersebut jelas jumlah dan jatuh temponya

$>$ Piutang tersebut diketahui dengan jelas harus ditagih kepada siapa.

b) Klasifikasi Piutang

Walaupun terdapat begitu banyak macam piutang yang memungkinkan dimiliki suatu koperasi, tetapi berdasarkan jenis dan asal piutang maka piutang di dalam koperasi dapat diklasifikasikan ke dalam dua kelompok, yaitu :

1. Piutang Anggota

Adalah piutang yang timbul dari penjualan barang atau jasa yang dihasilkan koperasi kepada anggota koperasi. Dalam kegiatan normal koperasi, piutang anggota biasanya akan dilunasi dalam tempo kurang dari satu tahun makanya piutang anggota dikelompokkan ke dalam kelompok aktiva lancar.

2. Piutang Bukan Anggota

Adalah piutang yang timbul akibat koperasi melakukan transaksi kredit kepada bukan anggota koperasi.

c) Pengertian Pembiayaan

Pembiayaan merupakan suatu fasilitas yang diberikan Bank Islam kepada masyarakat yang membutuhkan untuk menggunakan dana yang telah dikumpulkan oleh Bank Islam dari masyarakat yang surplus dana.

Pembiayaan menurut UndangUndang Perbankan Nomor 10 Tahun 1998 adalah penyediaan uang atau tagihan yang dapat dipersamakan dengan itu, berdasarkan persetujuan atau kesepakatan antar bank dengan lainnya yang mewajibkan pihak yang dibiayai untuk mengembalikan uang atau tagihan tersebut setelah jangka waktu tertentu dengan imbalan atau bagi hasil (Kasmir, 2014:92).

Pembiayaan ini diberikan melalui surplus yang diberikan masyarakat yang menyimpan di Bank Islam yaitu lembaga keuangan syariah lainnya. Orientasi pembiayaan yang diberikan Bank Islam adalah untuk sasaran mengembangkan dan atau meningkatkan pendapatan nasabah dan Bank Islam.

\section{d) Pengertian Kredit}

Menurut

Undang-Undang

Perbankan Nomor 10 Tahun 1998, kredit adalah penyediaan uang atau tagihan yang dapat dipersamakan dengan itu, berdasarkan persetujuan atau kesepakatan pinjam meminjam antar bank dengan pihak lain yang mewajibkan pihak peminjam melunasi utangnya setelah jangka waktu tertentu dengan pemberian bunga (Kasmir, 2014:92).

Yang menjadi perbedaan antara kredit yang diberikan oleh bank berdasarkan konvensional dengan pembiayaan yang diberikan oleh bank berdasarkan prinsip syariah adalah terletak pada keuntungan yang diharapkan. Bagi bank berdasarkan prinsip konvensional keuntungan yang diperoleh melalui bunga sedangkan bagi bank yang berdasarkan prinsip bagi hasil berupa imbalan bagi hasil.

Pemberian kredit tanpa dianalisis terlebih dahulu akan sangat membahayakan bank. Nasabah dalam hal ini dengan mudah memberikan data-data fiktif sehingga kredit tersebut sebenarnya tidak layak untuk diberikan. Akibatnya jika salah dalam menganalisis, maka kredit yang disalurkan akan sulit untuk ditagih alias macet. 
Namun faktor salah analisis ini bukanlah merupakan penyebab utama kredit macet malaupun sebagian terbesar kredit macet diakibatkan salah dalam mengadakan analisis. Penyebab lainnya mungkin disebabkan oleh musibah yang tidak dapat dihindari oleh nasabah.

\section{9) Unsur-Unsur Pembiayaan/Kredit}

Menurut Kasmir (2014:94) unsurunsur pembiayaan/kredit meliputi:

a. Kepercayaan

Yaitu suatu keyakinan pemberi pembiayaan bahwa pembiayaan yang diberikan berupa uang, barang, atau jasa akan benarbenar diterima kembali dimasa mendatang.

b. Kesepakatan

Yaitu kesepakatan antara pemberi pembiayaan dengan si penerima pembiayaan. Kesepakatan ini dituangkan dalam suatu perjanjian dimana masing-masing pihak menandatangani hak dan kewajiban masing-masing.

c. Jangka waktu

Setiap pembiayaan yang diberikan pasti memiliki jangka waktu tertebtu, jangka waktu ini mencakup masa pengembalian pinjaman yang telah disepakati.

d. Resiko

Faktor resiko kerugian dapat diakibatkan dua hal yaitu resiko kerugian yang diakibatkan nasabah sengaja tidak membayar pinjaman pada hal mampu untuk membayar dan resiko kerugian yang diakibatkan karena nasabah tidak sengaja yaitu terjadi musibah seperti bencana alam, kebakaran, meninggal dunia.

e. Balas Jasa

Merupakan keuntungan atas pemberian suatu kredit atau jasa tersebut yang kita kenal dengan nama bunga. Balas jasa dalam bentuk bunga dan biaya administrasi kredit ini merupakan keuntungan bank. Sedangkan bagi bank yang berdasarkan prinsip syariah balas jasanya ditentukan dengan bagi hasil.

\section{0) Jenis-Jenis Pembiayaan/Kredit}

Menurut Kasmir (2014:99) pembiayaan dapat di lihat dari berbagai segi antara lain:

a) Dilihat dari segi tujuan pembiayaan

$>$ Pembiayaan Produktif

Pembiayaan produktif adalah yang digunakan untuk peningkatan usaha atau produksi atau investasi. Pembiayaan ini diberikan untuk menghasilkan barang atau jasa.

Pembiayaan Konsumtif

Pembiayaan konsumtif adalah pembiayaan yang digunakan untuk konsumsi secara pribadi (contoh pembiayaan perabotan rumah tangga, pembiayaan mobil pribadi).

> Pembiayaan Perdagangan

Pembiayaan perdagangan adalah pembiayaan yang digunakan untuk perdagangan, biasanya untuk membeli barang dagangan, yang pembayarannya diharapkan dari hasil penjualan barang dagangan tersebut.

b) Pembiayaan dilihat dari segi kegunaan

$>$ Pembiayaan investasi yaitu pembiayaan yang digunakan untuk keperluan perluasan usaha atau membangun proyek atau pabrik baru.

> Pembiayaan modal kerja yaitu pembiayaan yang digunakan untuk keperluan peningkatan produksi dalam operasionalnya.

c) Dilihat dari segi jangka waktu

$>$ Pembiayaan jangka pendek

Merupakan pembiayaan yang memiliki jangka waktu kurang dari 1 tahun atau paling lama 1 tahun dan biasanya digunakan untuk 
keperluan modal kerja. Contoh untuk perternakan misalnya pembiayaan peternakan ayam atau jika untuk pertanian misalnya tanaman padi atau palawija.

- Pembiayaan jangka menegah Jangka waktu kreditnya berkisar antara 1 tahun sampai dengan 3 tahun, biasanya untuk investasi. Sebagai contoh pembiayaan untuk pertanian jeruk, atau peternakan kambing.

Pembiayaan jangka panjang

Merupakan pembiayaan yang masa pengembaliannya paling panjang. Pembiayaan jangka panjang waktu pengembaliannya di atas 3 tahun atau 5 tahun. Biasanya untuk investasi jangka panjang seperti perkebunan karet, kelapa sawit dan lain-lain.

d) Dilihat dari segi jaminan

$>$ Pembiayaan dalam jaminan

Pembiayaan yang diberikan dengan suatu jaminan, jaminan tersebut dapat berbentuk barang berwujud atau tidak berwujud atau bias juga jaminan orang. Artinya setiap pembiayaan yang dikeluarkan akan dilindungi senilai jaminan yang diberikan si calon debitur.

> Pembiayaan tanpa jaminan

Merupakan pembiayaan yang diberikan tanpa jaminan barang atau prang tertentu. Pembiayaan jenis ini diberikan dengan melihat prospek usaha dan karakter serta loyalitas atau nama baik si calon debitur selama ini.

e) Dilihat dari segi sektor usaha

$>$ Pembiayaan pertanian, merupakan pembiayaan yang dibiayai untuk sektor perkebunan atau pertanian rakyat. Sektor usaha pertanian dapat berupa jangka pendek atau jangka panjang.

$>$ Pembiayaan peternakan, dalam hal ini untuk jangka pendek misalnya peternakan ayam dan untuk jangka panjang misalnya kambing atau sapi.

$>$ Pembiayaan industri, yaitu pembiayaan untuk membiayai industri kecil, menengah atau besar.

$>$ Pembiayaan pertambangan, jenis usaha tambang yang dibiayainya biasanya dalam jangka panjang, seperti tambang emas, minyak atau timah.

$>$ Pembiayaan pendidikan, merupakan pembiayaan yang diberikan untuk membangun sarana dan prasarana pendidikan atau dapat pula berupa pembiayaan untuk para mahasiswa.

> Pembiayaan profesi, diberikan kepada para professional seperti dosen, dokter atau pengacara.

$>$ Pembiayaan perumahan, yaitu pembiayaan untuk membiayai pembangunan atau pembelian perumahan dan sektor lain-lain.

\section{1) Pengertian Sistem Pemberian Pembiayaan}

Proses pemberian pembiayaan memerlukan jangka waktu yang cukup panjang, karena proses jangka pemberian pembiayaan akan selalu di hadapkan pada hal-hal dimasa yang akan dating yang tidak pasti. Oleh karena itu perusahaan selalu dituntut kemampuan untuk memperkirakan kejadian-kejadian yang akan berlangsung pada masa yang akan datang.

Sistem pemberian pembiayaan merupakan cara yang ditetapkan oleh bank dengan maksud untuk mempermudah nasabah dalam memberikan pinjaman atau suatu cara yang harus ditempuh oleh debitur dalam memperoleh dana dari perusahaan atau lembaga perkreditan. 


\section{2) Tujuan Sistem Pemberian Pembiayaan}

Seiring berkembangnya suatu kegiatan perekonomian suatu perusahaan dalam sistem pemberian pembiayaan, oleh karena itu pertumbuhan suatu kegiatan perekonomian ataupun pertumbuhan suatu kegiatan usaha dari suatu perusahaan dengan eksitensi perkreditan mempunyai hubungan yang erat.

Pemberian suatu fasilitas pembiayaan mempunyai tujuan tertentu. Tujuan pemberian pembiayaan tersebut tidak akan terlepas dari misi bank tersebut didirikan.

Menurut Kasmir (2014:96) tujuan utama pemberian suatu pembiayaan antara lain:

a) Mencari keuntungan

Yaitu bertujuan untuk memperoleh hasil dari pemberian kredit tersebut. Hasil tersebut terutama dalam bentuk bunga dan dalam istilah koperasi pembagian SHU yang diterima oleh bank/koperasi sebagai balas jasa dan biaya administrasi pembiayaan yang dibebankan kepada nasabah.

b) Membantu usaha nasabah

Tujuan lainnya adalah untuk membantu usaha nasabah yang memerlukan dana, baik dana investasi maupun dana untuk modal kerja.dengan data tersebut, maka debitur akan dapat mengembangkan dan memperluaskan usahanya.

\section{3) Prosedur Dalam Pemberian Pembiayaan \\ Prosedur dalam pemberian} pembiayaan oleh perusahaan secara umum antar perusahaan yang satu dengan perusahaan yang lain tidak jauh berbeda. Syarat-syarat atau petunjuk tindakan-tindakan yang harus dilakukan sejak diajukannya permohonan nasabah sampai dengan luasnya suatu kredit yang diberikan oleh perusahaan.

Menurut Kasmir (2014:110) prosedur dalam pemberian kredit oleh dunia perbankan secara umum antara bank yang satu dengan bank yang lain tidak jauh berbeda. Yang mungkin jadi perbedaan mungkin hanya terletak dari prosedur dan persyaratan yang ditetapkannya dengan pertimbangan masing-masing.

Prosedur pemberian kredit secara umum dapat dibebankan antara pinjaman perseorangan dengan pinjaman oleh suatu badan hukum, kemudian dapat pula ditinjau dari segi tujuannya apakah untuk konsumtif atau produktif.

\section{4) Kreteria}

\section{Pembiayaan/Kredit}

Penilaian

Menurut Mulyadi (2015:104-105) kreteria penilaian kredit menggunakan analisis $5 \mathrm{C}$ yaitu:

1. Charaacter

Suatu keyakinan bahwa, sifat atau watak dari orang-orang yang akan diberikan kredit benar-benar dapat dipercaya, hal ini tercermin dari latar belakang si nasabah baik yang bersifat latar belakang pekerjaan maupun yang bersifat pribadi seperti: cara hidup atau gaya hidup yang dianutnya, keadaan keluarga, hoby dan sosial standingnya. Ini merupakan ukuran "kemauan" membayar.

2. Capacity

Untuk melihat nasabah dalam kemampuannya dalam bidang bisnis yang dihubungkan dengan pendidikannya, kemampuan bisnis juga diukur dengan kemampuannya dalam memahami tentang ketentuan-ketentuan pemerintah. Begitu pula dengan kemampuannya dalam menjalankan usahanya 
selama ini. Pada akhirnya akan terlihat "kemampuannya" dalam mengembalikan kredit yang disalurkan.

3. Capital

Untuk melihat penggunaan modal apakah efektif, dilihat laporan kauangan (neraca dan laporan rugi laba) dengan melakukan pengukuran seperti dari segi likuiditas, solvabilitas, rentabilitas dan ukuran lainnya. Capital juga harus dilihat dari sumber mana saja modal yang ada sekarang ini.

4. Colleteral

Merupakan jaminan yang diberikan calon nasabah baik yang bersifat fisik maupun non fisik. Jaminan hendaknya melebihi jumlah kredit yang diberikan. Jaminan juga harus diteliti keabsahannya, sehingga jika terjadi suatu masalah, maka jaminan yang dititipkan akan dapat dipergunakan secepat mungkin.

5. Condition

Dalam menilai kredit hendaknya juga dinilai kondisi ekonomi dan politik sekarang dan dimasa yang akan datang sesuai sektor masingmasing, serta prospek usaha dari sektor yang ia jalankan. Penilaian prospek bidang usaha yang dibiayai hendaknya benar-benar memiliki prospek yang baik, sehingga kemingkinan kredit tersebut bermasalah relatif kecil.

\section{METODE PENELITIAN}

Dalam penelitian ini, penulis menggunakan metode analisis deskriptif kualitatif, yakni mengumpulkan data, menyusun data, menyajikan data, menginterpretasikan data serta mengambil suatu kesimpulan atas data-data yang telah dikumpulkan tersebut.

\section{E. POPULASI DAN SAMPEL}

1) Populasi
Menurut Arikunto (2013:108), "Populasi adalah keseluruhan subjek penelitian". Penelitian ini difokuskan pada evaluasi prosedur pemberian pembiayaan dan hubungannya dengan kredit macet pada Koperasi Tunas Perkebunan Belitang OKU Timur selama tiga tahun dari tahun 2015 sampai dengan tahun 2017.

\section{2) Sampel}

Sampel adalah sebagian atau wakil populasi penelitian (Arikunto, 2013:109). Selanjutnya menurut Arikunto (2013:112), "Apabila subjek yang diteliti kurang dari 100 , lebih baik diambil semua sehingga penelitiannya merupakan penelitian populasi, sedangkan jika jumlah subjeknya lebih dari 100 , maka diambil $10 \%-15 \%$ atau 20\%-25\% tergantung dari kemampuan peneliti yang dilihat dari segi waktu dan luasnya wilayah penelitian".

Berdasarkan pendapat tersebut di atas, penulis mengambil keseluruhan populasi yang ada sebagai sampel dalam penelitian ini.

\section{F. Teknik Pengumpulan Data}

Metode pengumpulan data yang peneliti gunakan dalam penelitian ini aalah sebagai berikut:

1. Observasi

Yaitu pengumpulan data dengan cara mengadakan pengamatan langsung keadaan yang ada pada suatu organisasi atau instansi yang diteliti yakni tentang analisa alat perlengkapan organisasi dan pegawasan dalam menunjang kinerja karyawan, dalam hal ini Koperasi Tunas Perkebunan Belitang OKU Timur.

2. Wawancara

Wawancara merupakan instrumen pengumpul data yang digunakan penulis untuk memperoleh informasi langsung dari sumbernya tentang analisa alat 
perlengkapan organisasi dan pegawasan dalam menunjang kinerja karyawan.

\section{G. TEKNIK ANALISIS DATA}

Teknis analisis yang digunakan dalam penelitian ini yakni dengan menggunakan metode Deskriptif Kualitatif yaitu dengan memberikan uraian yang dapat digunakan dalam menjelaskan masalah yang ada di Koperasi Tunas Perkebunan Belitang OKU Timur menyangkut prosedur akuntansi atas pemberian pembiayaan dan hubunganya dengan kredit macet.

\section{H. HASIL PENELITIAN}

Berdasarkan uraian dari bab sebelumnya, penulis mencoba untuk mengevaluasi tentang prosedur pemberian pembiayaan dan hubungannya dengan kredit macet pada Koperasi Tunas Perkebunan Belitang OKU Timur.

\section{$>$ Evaluasi Prosedur Pemberian Pembiayaan Sesuai dengan Akuntansi Koperasi yang Berlaku Umum.}

a) Prosedur Pemberian Pembiayaan Pembiayaan merupakan salah satu jenis program yang ada di Koperasi Tunas Perkebunan Belitang OKU Timur. Pembiayaan ini diberikan untuk membantu masyarakat, khususnya masyarakat golongan menengah ke bawah yang membutuhkan bantuan dana untuk membangun suatu usaha guna memenuhi kebutuhan hidup mereka.

$$
\text { Pada Koperasi Tunas }
$$

Perkebunan Belitang OKU Timur aktivitas pemberian pembiayaan dikelola oleh unit usaha simpan pinjam. Sebelum pembiayaan diberikan harus melalui tahapan tersendiri, hal ini dimaksudkan untuk:
1. Keamanan dan kelancaran pembiayaan yang diberikan serta pembayarannya.

2. Bahwa anggota yang menerima pembiayaan memang benar-benar membutuhkannya dan pembiayaan yang diberikan pada anggota disesuaikan dengan kebutuhan dan permohonan untuk yang bersangkutan.

3. Pemberian jasa pembiayaan dilakukan koperasi dengan menerapkan prosedur-prosedur yang harus dipatuhi oleh anggotannya. Adapun alur prosedur pemberian pembiayaan tersebut, dapat dilihat pada bagan alir, sebagai berikut:

- Di jelaskan bahwa prosedur yang terjadi pada Koperasi Tunas Perkebunan Belitang OKU Timur, anggota dan non anggota yang memerlukan pembiayaan harus mengisi formulir permohonan pinjaman, membuat surat perjanjian dan surat pernyataan yang sudah ditandatangani suami/istri yang formulirnya diberikan oleh pihak Koperasi Tunas Perkebunan Belitang OKU Timur pada bagian pembiayaan.

- Bagian pembiayaan akan melakukan wawancara dengan calon peminjam serta akan ditanyakan tentang maksud dan tujuan melakukan pembiayaan, serta melengkapi syarat-syarat untuk mendapatkan pembiayaan. Dilakukan survei ke lapangan yang dilakukan oleh bagian pembiayaan tetapi dilakukan untuk anggota yang baru saja.

- Bila persyaratan dipenuhi, bagian pembiayaan akan membuat surat persetujuan bila "Ya" dan bila "Tidak" selesai, berkas yang sudah 
ditandatangani oleh manajer USP dan bagian pembiayaan, kemudian diserahkan pada teller USP untuk membuat bukti pengeluaran kas berupa kwitansi 2 lembar yang nantinya akan di serahkan kebagian administrasi piutang anggota dan anggota, bukti pengeluaran kas dipergunakan untuk mengeluarkan/pencairan uang.

- Bagian administrasi dan umum yang tugasnya menangani masalah piutang anggota pada Koperasi Tunas Perkebunan Belitang OKU Timur, juga melakukan penerimaan dan pencatatan bukti pengeluaran kas serta berkas-berkas ke dalam buku pembiayaan, kemudian berdasarkan bukti tersebut akan dibuat laporan pengeluaran harian dan di serahkan ke bagian teller USP.

- Setiap akhir bulan akan hasilkan laporan pengeluaran bulanan dari bagian teller USP untuk kemudian diserahkan ke manajer USP dan akan dilakukan pengecekan ke dalam daftar nama peminjam oleh manajer USP.

Dapat penulis simpulkan dari alur prosedur tersebut di atas bahwa tidak dilakukan survai lagi bagi anggota lama yang ingin melakukan pembiayaan kembali padahal kondisi ekonomi anggota dapat berubah-ubah setiap saat. Dan bagian teller USP hanya membuat bukti kas keluar berupa kwitansi sebanyak 2 rangkap yang nantinya diserahkan kebagian adminstrasi dan untuk anggota. Bagian pembiayaan juga melakukan penerimaan dan pencatatan bukti kas keluar yang seharusnya dilakukan bagian teller USP.
Dari alur prosedur pembiayaan pada Koperasi Tunas Perkebunan Belitang OKU Timur dapat dikatakan bahwa prosedurnya sudah baik tetapi sistemnya belum berjalan dengan baik, sehingga menyebabkan terjadinya kredit macet yang tiap tahunya berfluktuasi antara lain pada tahun 2015, jumlah kredit sebesar Rp 238.100.000, sedangkan jumlah kredit macet sebesar Rp 50.960.000 atau 21 \%. Pada tahun 2016 jumlah kredit sebesar Rp 510.593.075, sedangkan jumlah kredit macet mengalami kenaikan sebesar Rp 100.900.000 atau $19 \%$. Pada tahun 2017 jumlah kredit mengalami peningkatan sebesar $\mathrm{Rp}$ 685.541.470 dan jumlah kredit macet meningkat sebesar $\mathrm{Rp} 150.750 .000$ atau $22 \%$, apabila kenaikan kredit macet tidak dapat dikurangi maka akan menyebabkan Koperasi BMT Palembang dapat kesulitan dalam memberikan atau menambah pembiayaan untuk anggota koperasi yang lain.

\section{PEMBAHASAN}

Sesuai dengan alur prosedur pembiayaan yang telah di lakukan pada Koperasi Tunas Perkebunan Belitang OKU Timur, yang sampai saat ini masih terdapat kredit macet yang sangat signifikan, maka untuk mengatasi permasalahan kredit macet tersebut penulis akan memberikan solusi, bagaimana prosedour pemberian pembiayaan pada Koperasi Tunas Perkebunan Belitang OKU Timur tidak mengalami kesulitan pada saat akan melakukan penagihan kepada anggotanya (peminjam) sebagai berikut:

a) Bagian Pembiayaan Yang harus dilakukan bagian pembiayan yaitu:

$>$ Menerima calon anggota yang ingin melakukan pembiayaan. 
- Menerima pengajuan permohonan dari calon anggota tersebut.

Menerima surat permohonan pembiayaan dari calon anggota.

$>$ Anggota mengisi formulir surat persetujuan pembiayaan yang sudah di sediakan oleh koperasi, yang gunanya untuk mendapatkan persetujuan jumlah pinjaman yang ditujukan kepada manager USP.

$>$ Mengadakan wawancara dengan calon peminjam dan ditanyakan tentang maksud dan tujuan melakukan pembiayaan, dan survei ke lapangan yang di lakukan oleh bagian pembiayaan untuk anggota baru atau anggota lama yang ingin melakukan pembiayaan kembali.

$>$ Menerima kelengkapan persyaratan berupa copi KTP 1 lembar, copy KK 1 lembar, bukti pembayaran PBB dan bukti pembayaran rekening.

> Mencatat dalam buku peminjam

$>$ Mencatat dalam daftar nama peminjam

- Pada akhir bulan akan di hasilkan nama-nama calon peminjam

- Mendapatkan persetujuan dari bagian pembiayaan dan manajer USP

- Membuat surat persetujuan pembiayaan yang di berikan untuk anggota.

- Anggota membuat surat pernyataan suami/istri, surat perjanjian, surat permohonan pinjaman, surat persetujuan kredit/pembiayaan kemudian diserahkan ke bagian teller USP.

- Mencatat dalam kartu anggota dan menjadi anggota (peminjam) koperasi.

b) Bagian Teller USP

Yang harus dilakukan bagian

Teller USP yaitu:
$>$ Menerima berkas berupa surat pernyataan suami/istri, surat perjanjian, surat permohonan pinjaman, surat persetujuan kredit/pembiayaan dari bagian pembiayaan.

> Membuat bukti kas keluar.

$>$ Bukti kas keluar di gunakan untuk mengeluarkan uang dan di serahkan kepada anggota yang berbentuk kwitansi.

$>$ Kemudian surat pernyataan suami/istri, surat perjanjian, surat permohonan pinjaman, surat persetujuan kredit/pembiayaan ditambah dengan bukti kas keluar sebanyak tiga rangkap yang nantinya akan diserahkan ke bagian teller, administrasi dan umum, dan anggota kemudian diserahkan ke bagian adminstrasi dan umum.

$>$ Membuat laporan pengeluaran harian (LPH) dan di serahkan kebagian adminstrasi dan umum.

$>$ Membuat rekap laporan pengeluaran harian.

- Pada akhir bulan akan di hasilkan laporan pengeluaran bulanan.

$>$ Membuat laporan bulanan (Kwitansi).

c) Bagian Adminstrasi dan umum Yang harus dilakukan bagian adminstrasi dan umum yaitu:

$>$ Menerima berkas dari bagian teller USP yang berupa surat pernyataan suami/istri, surat perjanjian, surat permohonan pinjaman, bukti kas keluar 1 lembar.

$>$ Mencatat dalam kartu anggota.

$>$ Kartu pembiayaan uang

$>$ Jurnal pengeluaran.

$>$ Laporan pengeluaran harian

- Pada sore hari akan dihasilkan laporan pengeluaran harian.

$>$ Kemudian proses komputerisasi 
- Pada akhir bulan akan dihasilkan laporan pengeluaran bulanan.

$>$ Akan dihasilkan laporan pendukung berupa laporan pengeluaran bulanan.

d) Bagian Manajer USP

Yang harus dilakukan bagian manajer USP yaitu:

$>$ Menerima laporan pengeluaran bulanan

> Kemudian mengecek ke daftar nama peminjam.

$>$ Mengadakan pengecekan untuk memeriksa kebenaran laporan pengeluaran bulanan yang diterima dari bagian adminstrasi.

$>$ Proses selesai.

Jadi dari pembahasan tersebut di atas, dapat di simpulkan bahwa:

1. Bagian Pembiayaan tugasnya menerima permohonan, surat permohonan pinjaman, mengadakan wawancara dengan calon anggota dan melakukan survei, mencatat dalam buku peminjam dan daftar nama peminjam, memberikan persetujuan selain dari manajer USP kemudian membuat surat persetujuan kredit/pembiayaan yang dilengkapi dengan berkas-berkas kemudian mencatatnya dalam kartu anggota.

2. Bagian teller USP tugasnya menerima berkas-berkas dari bagian pembiayaan, kemudian dibuatkannya bukti kas keluar sebanyak tiga rangkap yang akan deberikan ke bagian adminstrasi dan umum,anggota dan bagian teller itu sendiri, membuat laporan pengeluaran harian (piutang anggota) dan melakukan perekapan atas laporan yang telah di buatnya.

3. Bagian adminstrasi dan umum tugasnya menerima berkas-berkas dari bagian teller USP kemudian melakukan pencatatan dalam kartu anggota dan kartu pembiayaan uang selanjutnya membuat jurnal pengeluaran kas, laporan pengeluaran harian dan memprosesnya ke dalam komputerisasi dan dihasilkan laporan pendukung .

4. Bagian manajer USP tugasnya menerima laporan pengeluaran bulanan dari bagian adminstrasi dan kemudian mengadakan pengecekan untuk memeriksa kebenaran laporan tersebut.

\section{Evaluasi Faktor-Faktor 5 C Dalam Menghindari Kredit Macet}

Analisis $5 \mathrm{C}$ yang terdiri dari character, capacity, capital, colleteral, dan condition merupakan alat dalam prosedur pemberian pembiayaan agar pembiayaan yang diberikan tidak mengalami kemacetan dikemudian hari.

Adapun analisis 5 C dapat ditentukan dengan melihat kondisi kehidupan anggota sehari-hari, misalnya:

a. Character

Menunjukkan kemampuan dari anggota untuk bersikap jujur. Disini anggota memiliki gaya hidup yang tidak baik atau suka berbohong atau adanya unsur kesengajaan untuk tidak membayar atau menunda membayar angsuran. Dalam hal ini anggota sengaja untuk tidak bermaksud untuk tidak membayar pada hal anggota mampu untuk membayarnya sehingga kredit yang diberikan manjadi macet. Dapat dikatakan tidak adanya unsur kemauan untuk membayarnya.

b. Capacity

Capacity adalah kemampuan anggota untuk mengembalikan pembiayaan yang telah diberikan. 
Disini anggota menggunakan uang hasil dari pinjaman tadi untuk keperluan pribadi tidak digunakan untuk membuka usaha, sehingga pada saat melakukan angsuran tidak ada danannya karena sudah habis untuk keperluan yang bersifat konsumtif.

c. Capital

Anggota tidak dapat melunasi angsuran karena usaha yang dijalankan tidak mengalami perkembangan atau peningkatan dikerenakan anggota tidak memiliki kemampuan di bidang usaha atau kurang berpengalaman dalam melakukan pemasaran barang dagangannya sehingga jadi bangkrut atau gulung tikar akhirnya kesulitan dalam melakukan pembayaran angsuran kepada koperasi.

\section{d. Collateral}

Faktor ini mencerminkan jaminan yang diberikan oleh anggota. Di Koperasi Tunas Perkebunan Belitang OKU Timur ini kebanyakan anggotanya terdiri dari masyarakat golongan menengah ke bawah sehingga tidak dapat memberikan jaminan yang signifikan bagi koperasi.

\section{e. Condition}

Menunjukkan pengaruh langsung dari trend ekonomi pada umumnya, sehingga anggota kesulitan untuk melakukan angsuran karena kondisi ekonomi yang terus memburuk, seperti adanya kenaikan harga BBM, harga sembako yang terus melambung tinggi dan ketiadaan lapangan pekerjaan, sehingga daya beli masyarakat berkurang karena pendapatan yang tetap/kecil dan kebutuhan anggota yang terus meningkat.
Dari unsur-unsur $5 \mathrm{C}$ tersebut di atas dapat disimpulkan bahwa:

1. Character

Tidak adanya unsur kemauan untuk membayarnya di karenakan tidak adanya konfirmasi untuk membayar pinjaman sampai saat terjadi jatuh tempo serta tidak ada petugas pada saat penagihan untuk mendatangi rumah anggota untuk mengkonfirmasikan masalah pembiayaan yang akan mengalami kemacetan kepada anggota.

2. Capacity

Tidak ada keinginan untuk melakukan usaha, sehingga hasil dari pembiayaan tadi tidak di pergunakan untuk usaha melainkan untuk kepentingan atau keperluan yang bersifat konsumtif/pribadi di karenakan tidak ada niat untuk menjalankan usaha.

3. Capital

Usaha yang dijalankan tidak mengalami perkembangan/peningkatan dikarenakan tidak memiliki jiwa untuk berwirausaha sehingga kemampuan, pengalaman yang di miliki untuk berwirausaha kurang.

4. Collateral

Kebanyakan anggota yang melakukan pembiayaan golongan menengah kebawah, sehingga tidak ada jaminan yang signifikan untuk koperasi, kebanyakan anggotanya pedagang manisan atau tempat usahanya kecil, tempat tinggalnya ngontrak atau ikut orang tua atau orang lain/numpang.

\section{Condition}

Para anggota yang tidak memiliki pekerjaan/penghasilan tetap, apalagi adanya dampak dari 
kenaikan harga BBM, harga sembako yang terus melambung tinggi, sehingga daya beli masyarakat berkurang karena pendapatan yang tetap dan kebutuhan anggota yang terus meningkat.

\section{J. KESIMPULAN DAN SARAN}

a) Kesimpulan

Berdasarkan hasil evaluasi dan pembahasan dari bab sebelumnya terhadap evaluasi prosedur pemberian pembiayaan dan hubungannya dengan kredit macet pada Koperasi Tunas Perkebunan Belitang OKU Timur tidak terlaksana dengan baik, hal ini dapat di lihat dari:

1) Bagian pembiayaan pada Koperasi Tunas Perkebunan Belitang OKU Timur, dalam prosedur pemberian pembiayaan kurang mengadakan pengecekan terhadap kelayakan besaran jumlah pembiayaan yang akan diberikan kepada calon anggota dan kurang pengecekan terhadap kebenaran informasi yang telah diberikan oleh calon peminjam.

2) Selain faktor bagian pembiayaan yang melaksanakan prosedur pemberian pembiayaan, kredit macet dapat pula terjadi dari sudut anggota itu sendiri, seperti:

a. Dapat dilihat dari watak atau sifat dari anggota yang tidak baik dikarenakan suka/sering berbohong pada saat melakukan pembayaran angsuran.

b. Dana pembiayaan yang diterima anggota tersebut tidak dipergunakan untuk usaha atau kegiatan yang bermanfaat melainkan untuk keperluan yang bersifat konsumtif/pribadi.

c. Kurangnya kemampuan dan pengalaman anggota yang melakukan/membuka usaha sendiri, menyebabkan usaha yang dijalankan dengan menggunakan dana pembiayaan menjadi tidak berkembang dan dapat gulung tikar.

d. Anggota yang melakukan pembiayaan kebanyakan golongan menengah ke bawah sehingga tidak dapat memberikan jaminan yang signifikan kepada koperasi.

e. Perubahan kondisi ekonomi yang terus memburuk, seperti kenaikan harga BBM, harga sembako yang terus melambung tinggi dan kurang tersedianya lapangan pekerjaan, menyebabkan kemampuan ekonomi anggota menjadi lemah.

\section{b) Saran}

Setelah menarik beberapa kesimpulan di atas dan berdasarkan hasil evaluasi pada bab sebelumnya, maka penulis mencoba untuk memberikan beberapa saran yang kiranya dapat berguna bagi Koperasi Tunas Perkebunan Belitang OKU Timur untuk mengatasi permasalahan yang terjadi dalam prosedur pemberian pembiayaan dan hubungannya dengan kredit macet, adapun saran-saran yang dapat penulis berikan adalah sebagai berikut:

1. Bagian pembiayaan pada Koperasi Tunas Perkebunan Belitang OKU Timur hendaknya lebih teliti lagi dalam menjalankan prosedur pemberian pembiayaan terhadap kelayakan besaran pembiayaan yang akan diberikan kepada calon peminjam dan lebih cermat terhadap kebenaran informasi yang telah diberikan oleh calan peminjam, sehingga kemungkinan untuk menunggak atau macet pada saat pembayaran dapat dicegah.

2. Bagian pembiayaan pada Koperasi Tunas Perkebunan Belitang OKU Timur harus dapat menganalisa anggota terlebih dahulu sebelum 
memberian pembiayaan, dapat juga dilakukan dengan cara menggunakan analisis $5 \mathrm{C}$, yaitu:

a. Sebaiknya pihak koperasi terutama bagian pembiayaan mengadakan penagihan langsung ke rumah anggota, sehingga anggota yang mempunyai kebiasaan tidak baik/suka berbohong tidak lagi berbuat bohong karena kondisi ekonomi anggota sudah diketahui oleh pihak koperasi atau bagian pembiayaan.

b. Sebaiknya bagian pembiayaan lebih teliti/cermat dalam melakukan prosedur pemberian pembiayaan, sehingga pembiayaan yang akan diberikan benar-benar untuk usaha atau keperluan yang bermanfaat dan tidak untuk keperluan yang bersifat konsumtif/pribadi.

c. Sebaiknya pihak koperasi memberikan pelatihan dan pembinaan secara berkala dan berkesinambungan bagi setiap anggotanya yang ingin melakukan atau membuka usahanya sehingga usaha yang akan dijalankan nanti dapat maju dan berkembang sehingga dapat melakukan angsuran tepat pada waktunya dan tidak terjadi penunggakan.

d. Sebaiknya pihak koperasi lebih memperhitungkan

agunan/jaminan yang akan diberikan oleh anggota yang akan melakukan pembiayaan, sehingga jaminan tersebut sebanding dengan pembiayaan yang akan diterima oleh anggotanya nanti. e. Bagian pembiayaan sebaiknya memberikan saran kepada setiap calon anggota yang ingin melakukan pembiayaan untuk memprioritaskan penggunaan dana pembiayaan yang diterimanya untuk keperluan yang sangat penting dan berguna bagi keluarga di masa yang akan datang.

\section{DAFTAR PUSTAKA}

Arikunto, Suharsimi. 2013. Prosedur Penelitian Suatu Pendekatan Praktik. Edisi Revisi. Jakarta Renika Cipta

Hendar, Kusnadi, 2005, Ekonomi Koperasi, Edisi Kedua, Lembaga Penerbit Fakultas Ekonomi Universitas Indonesia, Yogyakarta.

Ikatan Akuntan Indonesia. (2009). "Standar Akuntansi Keuangan", PSAK No. 1 : Penyajian Laporan Keuangan. Jakarta : Salemba Empat.

Kasmir, 2014. Bank dan Lembaga Keuangan Lainnya, Rajawali Pres, Jakarta.

Mulyadi. 2015. Manajemen Sumber Daya Manusia (MSDM).Penerbit IN MEDIA, Bogor

Rudianto, 2006, Akuntansi Koperasi, Penerbit PT. Gramedia Widia Sarana Indonesia, Jakarta. 